\title{
THE CONTROL OF CALIFORNIAN THISTLE
}

\author{
P. W. HAYMAN, Waimate.
}

It does indeed give me great pleasure to read this paper on our experiences with hormone weed spraying dealing with the control and elimination of Californian thistle.

Our property is situated on the "tail-end" of the Willowbridge soil belt, and consequently is subject to severe infestation with this weed. As you are all aware, during and after the war labour has been increasingly difficult to engage, and also more costly; as a result Californian thistle has become what could be termed a major problem.

I wish to preface my further remarks by explaining that most of cur experience has been with the M.C.P. type of hormone spray, which we consider the safest in cereal and potato crops.

As soon as the M.C.P. sprays became available a weed sprayer of the high volume, high pressure type was constructed, having a 200 -gallon tank, $16 \mathrm{ft}$. boom and high pressure pump, operated from the power take off of the tractor. The pump delivered 60 to 801 b. p.s.i., the nozzles used being the ordinary bordeaux type.

Our first experience was on a paddock so thickly infested that a dog would not try to force its way through the thistles. This was in a grass paddock. After spraying, the thistle showed the usual signs of being sprayed with a hormone weed killer-wilting and twisting. This was in early December; during the following 3 months after a period of 4 to 5 weeks the paddock was heavily stocked with ewes, and they grazed the thistles as if they were rape. About a month later it was ploughed, and during the winter was given another 2 ploughings. The ground was cultivated before the second and third ploughing, using a cultivator fitted with wide hoes. After the final deep ploughing this paddock was cultivated several times and then planted in potatoes. An examination of the thistle roots before the ground was ploughed showed that about 80 per cent. of the roots were affected by the spraying, but about 20 per cent. of the laterals were not, and appeared to be quite healthy. Above ground very few live plants were evident. The potato crop in next December still had a considerable thistle population, and it was decided to spray it; about 12 acres of the total 27 were treated at $0.51 b$. acid equivalent per acre. A slight wilt was noticed in the potato leaves the next day, but from then on no harmful effects could be seen. This spraying caused practically all the thistles above ground to die. A few roots, however, were still alive.

Following the potatoes, a crop of wheat was planted and all patches of thistles were sprayed just before the wheat came out in ear. This spraying, although perhaps seeming to be late, effectively checked all thistle growth, and when harvested with the binder the wheat presented no bother at all with thistles, as they were all dead and had shrivelled from a length of $3 \frac{1}{2} \mathrm{ft}$. to about 7 to 10in. The spraying of thistres in wheat appears to be the most effective way of dealing with thistles, but it must be remembered and stressed that it is a long-term policy. The control has always in our experience been most effective, but eradication is definitely a long-term policy. We believe that spraying, coupled with cultivation, will virtually eliminate the thistle menace on our property.

Up till now I have dealt with the control of Californian thistle in crops, i.e., potatoes, and wheat; regarding the spraying of thistles on grass paddocks which have not subsequently been ploughed, we have found that spraying each year has definitely reduced the size of the patches: 
for instance, an area of about 10 square yards with a plant every 2 to 4 in. apart after 4 sprayings has been reduced to a mere 10 to 12 plants.

It would appear that if the thistles were sprayed every year in grass over a period of say 5 to 6 years, they would be practically eliminated, and if this was followed up by further spraying when suitable crops were being grown it should be possible to eradicate them. This, however, is as yet theory, as we have not yet broken up pastures which we have sprayed over that length of time and cropped them.

Our observations are that if early (October) spraying is carried out there is quite a secondary growth during the autumn of plants growing close to the ground; if spraying is done during late November or early December, there is not such a regrowth. It would seem that the later spraying is more effective, as it does not allow the plant to build up a great supply of food in its root system before winter.

Potatoes: I would like to draw your attention to trials conducted by the Department of Agriculture, Waimate. These trials were carried out on slightly lighter country and it was noted that the crop matured earlier and the kill of thistles varied with different sprays used. The report also mentions danger of taint of tubers. This is a point of great importance and in all our subsequent sprayings we have kept the quantity below $0.5 \mathrm{lb}$. acid equivalent of the sodium salt of M.C.P. per acre. This, however, has been sufficient to check the thistle growth and the operation as compared to hand hoeing requires about $1 / 10$ to $1 / 15$ of the manpower previously needed.

We have come to the conclusion that the most effective control of thistles is in crop, either wheat or oats. These crops provide intensive competition to the thistle and appear to be unaffected by the hormone spray. The spraying of potatoes and pastures is regarded as essential only when severely infested with Californian thistle. Small patches of thistles that can be hand hoed in potatoes scarcely warrant spraying if they can be dealt with in a period of a few hours. If, however, several acres are involved, we regard it as a gcod policy to spray.

A point that we regard of some importance is the use of a high volume sprayer. It delivers approximately 100 gallons per acre and in vigorous crops such as Dreadnought wheat, the solution is driven down into the crop even on a moderately windy day. Low pressure machines, while doing a good job, are more subject to drifting of the spray, perhaps to a nearby susceptible crop, and we think do not in a thick crop reach all the thistles. At the same time, wetting as great an area as possible is important, as it must ensure maximum absorption. A low pressure, low volume machine, while wetting the topmost portions of the thistle, must have ideal conditions to moisten the maximum surface when the thistle is say $2 \mathrm{ft}$. $6 \mathrm{in}$. high and surrounded by wheat.

In conclusion, I would like to make a resume of the points I have mentioned.

1. Greatest control and kill when competition from crop is vigorous.

2. Quite effective with potatoes, but application must be low to avoid complications.

3. Large saving of man hours.

4. A long-term policy combining cultivation with spraying will obtain the best results.

\section{DISCUSSION}

Q. Have you had any brown spot on potatoes after spraying?

A. No ill effects at all have been noticed.

Q. What effect has hormone application in checking virus disease of potatoes?

A. All the seed used was brought from virus-free areas and hence no observations had been made. 